DOI: 10.12731/2658-6649-2019-11-5-81-86

УДК 612.017.1: 616.2

\title{
ПОКАЗАТЕЛИ КЛЕТОЧНОГО И ГУМОРАЛЬНОГО ЗВЕНЬЕВ ИММУНИТЕТА ПРИ РЕСПИРАТОРНОЙ АЛЛЕРГИИ В ЗАВИСИМОСТИ ОТ ГЕНЕЗА И УРОВНЯ ПОРАЖЕНИЯ РЕСПИРАТОРНОГО ТРАКТА
}

Лазарева А.М., Смирнова С.В., Коленчукова О.А.

В статье приводится исследование клеточного и гуморального звеньев иммунитета при респираторной атопии и псевдоатопии в зависимости от уровня поражения респираторного тракта. Изучаемые патологии: атопический риносинусит (AP; $n=28)$, атопическая бронхиальная астма (АБА; $n=28)$, полипозный риносинусит (ПРС; $n=68)$, астматическая триада (AT; $n=28)$. Группа контроля - здоровые люди (n=219). Гуморальное звено исследовали методом проточной ичитофлуориметрии, клеточное звено и ииркулирующие иммунные комплексы (ЦИК) - иммуноферментным анализом. Независимо от генеза аллергического воспаления верхних отделов (ПРС и $A P)$, установлено высокое содержание $C D 19^{+}$клеток относительно бронхиальной астмы, а для бронхиальной астмы (АТ и АБА) - CD $8^{+}$лимфочитов относительно контроля. При псевдоатопии (ПРС и АТ) снижена кониентрация SIgA и Clq относительно атопии (АР и АБА). В группе АР увеличено содержание sIgA относительно АБА. Для АТ характерно высокое количество $\mathrm{CD}^{+}, \mathrm{CD}^{+}$и низкое содержание $\mathrm{CD} 16^{+}$клеток относительно ПРС.

Ключевые слова: клеточный иммунитет; гуморальный иммунитет; атопический риносинусит; атопическая бронхиальная астма; астматическая триада; полипозный риносинусит.

\section{INDICATORS OF CELLULAR AND HUMORAL TYPES OF THE IMMUNITY IN PATIENTS WITH RESPIRATORY ATOPY AND PSEUDOATOPY DEPENDING ON THE LEVEL OF INJURY OF RESPIRATORY TRACT}

\section{Lazareva A.M., Smirnova S.V., Kolenchukova O.A.}

The article provides study of the cellular and humoral links of immunity against atopy and respiratory pseudoatopy depending on the level of the lesion respiratory 
tract. In the structure of the pathology were: atopic rhinosinusitis $(A R ; n=28)$, atopic asthma (ABA; $n=28)$, polypous rhinosinusitis (PRS; $n=68)$, asthmatic triad $(A T ; n=28)$. The control- healthy people, $n=219$. Humoral link was investigated using flow cytometry, cell link and CIC - by enzyme immunoassay. Regardless of the genesis of allergic inflammation of the upper respiratory tract (PRS and AR), a high content of $C D 19^{+}$cells relative to bronchial asthma, for bronchial asthma (AT and $A B A)-C D 8^{+}$relative to control. For pseudoatopy (PRS and $\left.A T\right)$ reduced the concentration SIgA and Clq regarding atopy (AR and ABA). The content of SIgA relative to $A B A$ was increased in the $A R$. AT is characterized by an increase in the number of $\mathrm{CD}^{+}, C D 4^{+}$and low amount of $C D 16^{+}$relative to PRS.

Keywords: cellular immunity; humoral immunity; atopic rhinosinusitis; atopic asthma; polypous rhinosinusitis; asthmatic triad.

\section{Введение}

Наиболее частыми проявлениями респираторной аллергии являются риносинусит и бронхиальная астма. Манифестация респираторной аллергии начинается с аллергического риносинусита с вовлечением нижних отделов респираторного тракта и развитием бронхиальной астмы. Аллергические поражения респираторного тракта гетерогенны $[1,2,3]$. Несмотря на то, что они чаще имеют в своей основе иммунопатологические (атопические) механизмы, существуют и неиммунологические (псевдоатопические), классическим примером которых являются полипозный риносинусит (ПРС) и аспириновая астма [4].

ПРС и аспириновая астма - проявления астматической триады (АТ), характеризующейся непереносимостью ненаркотических анальгетиков (НА) и нестероидных противовоспалительных препаратов (НПВП). Патогенез АТ связан с нарушением метаболизма арахидоновой кислоты (АК), образующейся из фосфолипидов клеточных мембран под действием фермента фосфолипазы А2. У АК существует два пути распада - циклооксигеназный и липоксигеназный. НА и НПВП ингибируют фермент циклооксигеназу и активируют альтернативный путь с образованием лейкотриенов. Лейкотриены - мощные медиаторы воспаления, хемотаксиса, расширения сосудов и повышения их проницаемости, увеличения секреции слизи, что реализуется бронхиальной констрикцией и бронхиальной астмой.

Таким образом, выделив иммунологические маркеры с учетом генеза аллергического воспаления и уровня поражения респираторного тракта, можно спрогнозировать вероятность прогрессирования патологии от АР к АБА и ПРС к АТ. 


\section{Материалы и методы}

Обследованы больные атопическим риносинуситом (AP, $\mathrm{n}=28)$, атопической бронхиальной астмой (АБА, $\mathrm{n}=28$ ), полипозным риносинуситом (ПРС, n=68), астматической триадой (AТ, n=32), в возрасте от 18 до 64 лет. Группу контроля составляли здоровые люди $(\mathrm{n}=209)$, сопоставимые по полу и возрасту с больными. Диагностика проводилась оториноларингологом и аллергологом-иммунологом. Гуморальное звено исследовали методом проточной цитофлоуметрии с использованием периферической крови, клеточное звено и ЦИКи - иммуноферментным анализом. Для статистической обработки использовали пакет прикладных программ Statistica 7.0. Выборка описана с подсчетом медианы интерквартильного размаха в виде 25 и 75 перцентилей. Достоверность различий оценивали по непараметрическому критерию Манна-Уитни. Критический уровень значимости при проверке статистических гипотез равен 0,05 .

\section{Результаты}

Во всех группах статистически значимо повышено содержание лейкоцитов и снижено процентное количество лимфоцитов относительно контроля $(\mathrm{P}<0,001)$. Концентрация $\mathrm{CD}^{+}{ }^{+}$и $\mathrm{CD}_{4}^{+}$лимфоцитов снижена в группах ПРС и АР относительно контроля ( $\mathrm{P}=0,003 ; \mathrm{P}=0,02 ; \mathrm{P}<0,001 ; \mathrm{P}=0,02)$.

$\mathrm{C}$ учетом уровня поражения, установлено повышенное содержание $\mathrm{CD}^{+}$и $\mathrm{CD}^{+}$лимфоцитов при АТ относительно ПРС (P=0,006; $\left.\mathrm{P}=0,03\right)$. При этом, процентное количество $\mathrm{CD} 8^{+}$лимфоцитов выше при АТ и АБА относительно контроля $(\mathrm{P}=0,02)$. Процентное содержание $\mathrm{CD} 16^{+}$лимфоцитов снижено при АТ относительно ПРС $(\mathrm{P}=0,04)$, а абсолютное- ниже относительно группы контроля $(\mathrm{P}=0,05)$.

Гуморальное звено характеризуется высоким относительным содержанием $\mathrm{CD} 19^{+}$лимфоцитов при АР относительно АБА и контроля $(\mathrm{P}=0,007$; $\mathrm{P}<0,001)$. В группе ПРС относительная концентрация $\mathrm{CD} 19^{+}$лимфоцитов выше группы АТ и контроля $(\mathrm{P}=0,004 ; \mathrm{P}=0,004)$.

Концентрация секреторного $\operatorname{IgA}$ в группах больных псевдоатопией (ПРС и АТ) ниже относительно группы контроля $(\mathrm{P}=0,03 ; \mathrm{P}=0,01)$, а в группе АР выше группы ПРС и АБА $(\mathrm{P}<0,001)$.

Концентрация $\mathrm{Clq}$ в группе AP выше чем в группе ПРС $(\mathrm{P}=0,03)$, а C3d в группах ПРС, АТ и АБА выше группы контроля $(\mathrm{P}=0,02 ; \mathrm{P}<0,001)$.

\section{Обсуждение}

Независимо от генеза аллергии верхних отделов (ПРС и АР) определена активация гуморального звена за счет повышенного содержания 
В-лимфоцитов относительно бронхиальной астмы. При распространении патологии от риносинусита к астме, наблюдается уменьшение количества $\mathrm{CD} 19^{+}$лимфоцитов. Для бронхиальной астмы (АТ и АБА) характерно высокое содержание $\mathrm{CD}^{+}$лимфоцитов относительно контроля. В группах больных респираторной псевдоатопией (ПРС и АТ) снижена концентрация sIgA и C1q относительно групп респираторной атопией (АР и АБА). Clq связан с классическим путем активации комплемента, что характерно для атопических механизмов. С $3 \mathrm{~d}$ - это компонент альтернативного пути активации комплемента. Констатируя факт высоких концентраций С $3 \mathrm{~d}$ при БА, независимо от генеза, можно говорить о более выраженных сдвигах в иммунном ответе по мере расширения шоковых территорий. В группе АР увеличено содержание sIgА относительно АБА. Вероятно, на фоне развития вторичного иммунодефицита концентрация IgA снижается по мере прогрессирования респираторной аллергии от риносинусита к бронхиальной астме. Для АТ характерно повышение количества $\mathrm{CD}^{+}$, $\mathrm{CD} 4^{+}$и снижение $\mathrm{CD} 16^{+}$лимфоцитов относительно ПРС.

\section{Заключение}

Таким образом, сравнение показателей гуморального и клеточного звеньев иммунитета при респираторной атопии и псевдоатопии, показал особенности иммунореактивности в зависимости от генеза и уровня аллергического воспаления. Снижение концентрации sIgA и CD19+лимфоцитов можно рассматривать как маркер прогрессирования респираторной атопии, а повышение концентраций $\mathrm{CD}^{+}, \mathrm{CD}^{+}$и снижение $\mathrm{CD} 16^{+}, \mathrm{CD} 19^{+-}$ лимфоцитов - как маркер прогрессирования псевдоатопии.

Информация о конфликте интересов. Авторы заявляют об отсутствии конфликта интересов.

Информация о спонсорстве. Исследование не имело спонсорской поддержки.

\section{Список литературы}

1. Коленчукова О.А., Смирнова С.В., Лаптева А.М. Особенности иммунологических и метаболических показателей при полипозном риносинусите // Вестник оториноларингологии. 2015. Т.80, № 6. С. 22-27.

2. Лазарева А.М., Смирнова С.В. Специфика иммунного статуса и назального микробиоценоза при развернутой астматической триаде//Медицинская иммунология. 2017. Т. 19. № S. С. 129. 
3. Смирнова С.В. Клинико-патогенетические варианты аллергической риносинусопатии // Пульмонология. Приложение. 2003. № 1. С. 223.

4. Smirnova S.V., Kolenchukova A.O., Lapteva A.M., Tereschenko S.U. Immune reactivity in allergic rhinosinusitis in association with its pathogenetic form // Allergy. 2015. Vol.70, №S101. P. 574.

\section{References}

1. Kolenchukova O.A., Kolenchukova O.A., Smirnova S.V. Osobennosti immunologicheskih i metabolicheskih pokazatelei pri polipoznom rinosinusite [Features of immunological and metabolic parameters in polypous rhinosinusitis]. Vestnik otorinolaringologii. 2015. V.80, № 6, pp. 22-27.

2. Lazareva A.M., Smirnova S.V. Specifika immunnogo statusa i nazalnogo mikrobiocenoza pri razvernutoi astmaticheskoi triade [The specificity of the immune status and nasal microbiota in deployed asthmatic triad]. Medicinskaya immunologiya. 2017. V. 19. № S, pp. 129.

3. Smirnova S.V. Kliniko-patogeneticheskie varianty allergicheskoi rinosinusopatii [Clinical and pathogenetic variants of allergic rhinosinusopathy]. Pulmonologiya. Prilozhenie. 2003. № 1, pp. 223.

4. Smirnova S.V., Kolenchukova A.O., Lapteva A.M., Tereschenko S.U. Immune reactivity in allergic rhinosinusitis in association with its pathogenetic form. Allergy. 2015. Vol.70, №S101, pp. 574.

\section{ДАННЫЕ ОБ АВТОРАХ}

Лазарева Анна Михайловна, очный аспирант

Научно-исследовательский институт медиииских проблем Севера - обособленного подразделения ФИЦ КНЦ СО РАН

ул. Партизана Железняка, 3 Г., г. Красноярск, 660022, Российская Федераиия

nuraaa@rambler.ru

Смирнова Светлана Витальевна, д.м.н., профессор, руководитель научного направления

Научно-исследовательский институт медицинских проблем Севера - обособленного подразделения ФИЦ КНЦ СО РАН

ул. Партизана Железняка, 3 Г., г. Красноярск, 660022, Российская Федераиия

Коленчукова Оксана Александровна, д.б.н., ведущий научный сотрудник лаборатории молекулярно-клеточной физиологии и патологии 
Научно-исследовательский институт медииинских проблем Севера - обособленного подразделения ФИЦ КНЦ СО РАН

ул. Партизана Железняка, 3 Г., г. Красноярск, 660022, Российская Федераичи

\section{DATA ABOUT THE AUTHORS}

Lazareva Anna Mickailovna, Post-graduate student

Research Institute of Medical Problems of the North - a separate division of the FIC KSC SB RAS

3 G, Partizana Zheleznyaka Str., Krasnoyarsk, 660022, Russian Federation nuraaa@rambler.ru

Smirnova Svetlana Vitalievna, $\mathrm{PhD}$, Professor, Head of the Scientific Direction Research Institute of Medical Problems of the North - a separate division of the FIC KSC SB RAS

3 G, Partizana Zheleznyaka Str., Krasnoyarsk, 660022, Russian Federation

Kolenchukova Oksana Alexandrovna, $\mathrm{PhD}$, leading researcher of the laboratory of molecular cell physiology and pathology

Research Institute of Medical Problems of the North - a separate division of the FIC KSC SB RAS

3 G, Partizana Zheleznyaka Str., Krasnoyarsk, 660022, Russian Federation 